\title{
How Concerned, Afraid and Hopeful Are We? Effects of Egoism and Altruism on Climate Change Related Issues
}

\author{
Igor Knez \\ Department of Social Work and Psychology, University of Gävle, Gävle, Sweden \\ Email: igor.knez@hig.se \\ Received June $17^{\text {th }}, 2013$; revised July $19^{\text {th }}, 2013$; accepted August $23^{\text {rd }}, 2013$
}

\begin{abstract}
Copyright $@ 2013$ Igor Knez. This is an open access article distributed under the Creative Commons Attribution License, which permits unrestricted use, distribution, and reproduction in any medium, provided the original work is properly cited.
\end{abstract}

\begin{abstract}
The idea that concerns for and emotional reactions to climate change may be due to environment-related egoism and altruism was tested. Participants assessed as "high" on egoism were shown to be more concerned for myself-related issues and afraid of the climate change impact on their local environment, indicating a self-benefit goal motive. Participants assessed as "high" on altruism were those more concerned for issues related to others and nature and more afraid and less hopeful for the whole world, indicating a pro-social goal motive in this group of individuals. This indicates that environment-related value orientations of egoism and altruism may prompt concerns and convey feelings differently about the climate change issue. Accordingly, when encouraging sustainable development, policy and pro-environmental actions, we have to bear in mind people's world views grounded in environment-related selfishness vs. unselfishness; indicating different goal-directed motives in climate change decision making.
\end{abstract}

Keywords: Egoism; Altruism; Concern; Fear; Hope; Climate Change Issues

\section{Introduction}

Consequences of climate change such as floods, heat waves and storms and their impact on society and our lifestyle are frequently in the news. According to some predictions an air temperature boost of $2^{\circ} \mathrm{C}-5^{\circ} \mathrm{C}$, due to anthropogenic greenhouse gas emissions, will drastically affect nature and in turn our ways of living (Koppe, Jendritzky, Kovats, \& Menne, 2004; IPCC, 2007; UNWTO, 2008). Climate change is not only an ecological and economic predicament (Markham, 1996; Hanson \& Ostrand, 2011), but also a social and psychological one (Stehr \& Storch, 1995; Saad, 2002; Schmuck \& Vlek, 2003) demanding sustainable development, policy and pro-environmental actions (UNCED, 1992; Smith \& Lenart, 1996; WRI, 2000; Sparks, Jessop, Chapman, \& Holmes, 2010).

Behavioral research of sustainable development have previously reported findings on climate-change-related behavior and risk judgment (Bonnes \& Bonaiuto, 2002; Sundblad, Biel, \& Gärling, 2007), moral and ethics (Ehrich, 2002; Hoffman \& Sandelands, 2005; Jordan, 2007; Posas, 2007; Karpiak \& Baril, 2008), emotions such as worry and hope (Boehnke, Fuss, \& Rupf, 2001; Ojala, 2007), as well as on how information and knowledge about climate change is disseminated, interpreted and understood (Wilson, 2000; Böhm \& Pfister, 2001; Stern, 2006; Sundblad, Biel, \& Gärling, 2009; Cook, Boyd, Grossmann, $\&$ Bero, 2009). In addition and due to the embedded conflict between an individual level of short-term self-interests ( $I$ will use my car, despite its production of harmful gases.) and a long-term collectivistic natural resource management (How can we decrease air pollution?), the climate change issue can also be conceptualized as a resource dilemma involving a conflict between the two types of interests (Hardin, 1968; Vugt, 2002;
Schmuck \& Vlek, 2003; Kortenkamp \& Moore, 2006; Biel and Thögersen, 2007).

Based on Schwartz $(1992 ; 1994)$ work on human values (see also Lewin, 1951; Batson, Van Lange, Ahmad \&Lishner, 2003) indicating relationships between value orientations, beliefs and concerns, several studies have moreover tried to extended this account as to comprise environmental issues (Stern, 2000; Schultz, 2001; Oreg \& Gerro, 2006; Hansla, Gamble, Juliusson, \& Gärling, 2008; Henry \& Dietz, 2012) involving social (Schultz, Gouveia, Cameron, Tankha, Schmuck, \& Franek, 2005; Stern \& Dietz, 1994) and spatial (Milfont, Abrahamse, \& McCarthy, 2011) conflicts. Given this, it is suggested that a value orientation of, for example, egoism (to benefit oneself) may antecede and positively correlate $\rightarrow$ with a belief that, for example, protecting the environment will threat jobs for people like me (awareness of consequences for oneself), which in turn may antecede and positively correlate $\rightarrow$ with myself-related concerns for, for example, my lifestyle and health (type of affect linked to consequences for oneself).

Previous research has also indicated effects of demographic variables on environment-related concerns (Olofsson \& Öhman, 2006) and emotions (Ojala, 2007). It is, for example, shown that women may be more concerned for and afraid of the climate change impact than men, and that less educated individuals may believe that claims about climate change are exaggerated (Knez, Thorsson, \& Eliasson, 2013). Regarding the environment-related emotions (Boehnke et al., 2001), it is furthermore reported that we may estimate local (increased number of cars) compare to global (increased anthropogenic greenhouse gas emission) environmental problems as less worrying (Garcia-Mira, Real, \& Romay, 2005); and that worriment may vary 
with gender, suggesting women to embrace environmental related altruistic values to a higher degree than do men (Ojala, 2007).

These types of feelings can also be classified as anticipatory vs. anticipated emotions (Loewenstein, Weber, Hsee, \& Welch, 2001). The former are faster bottom-up, viscelar processes compared to the latter, slower and analytically driven top-down processes of emotional anticipation. According to Weber (2006), people who show less concern for climate change issues do that because they do not have personal experience of environment-related problems. In emotion psychology terms, they have not as yet activated the fast visceral reactions of anticipatory emotions, but the slow top-down processes of emotional anticipation (see also Peters \& Slovic, 2000; Marx, Weber, Orlove, Leiserowitz, Krantz, Roncoli, \& Phillips, 2007). Accordingly, this suggests that decision making on long-term environmental risks is not only a cognitive activity but also an emotional one (Slovic, Finucane, Peters, \& MacGregor, 2002; Leiserowitz, 2006).

\section{Present Study}

Previous research, as above mentioned (Ehrich, 2002; Hoffman \& Sandelands, 2005; Jordan, 2007; Posas, 2007; Karpiak \& Baril, 2008), has indicated a link between sustainable policy and environmental ethics: "...we cannot get very far in discussing why climate change is a problem without invoking ethical considerations... we appear to need some account of moral responsibility, morally important interests, and what to do about that" (Gardiner, 2006: p. 398). This implies an intrinsic (We should care for the good of milieu, because it has a value independent of us.) compared to an instrumental (We should care for the good of milieu, because it satisfies our needs.) value (see Dietz, Fitzgerald, \& Shwom, 2005 for a review). As formulated by Leopold (1949/1987: p. 224): “A thing is right when it tends to preserve the integrity, stability, and beauty of the biotic community. It is wrong when it tends otherwise."

But, can we truly behave morally "right"; that is, altruistically? Or is our pro-sociality basically driven by egoistic motives? Alluding to this ancient debate (Schroeder, Penner, Dovidio, \& Piliavin, 1995; Cialdini, Brown, Lewis, Luce, \& Neuberg, 1997; Batson et al., 2003; Maner, Luce, Neuberg, Cialdini, Brown, \& Sagarin, 2002; Stocks, Lishner \& Decker, 2009) on whether: "...benefiting others is an instrumental goal on the way to some self-interested ultimate goal or an ultimate goal in its own right with the self-benefits being unintended consequences" (Batson et al., 2003: p. 281), the idea that people's concerns for, and emotions about, climate change may be due to environment-related egoism and altruism was tested. In other words, and alluding to Oceja and Salgado (2012): Does different world change orientations (in this study, values of altruism vs. egoism) convey different prosocial actions (in this study, concerns and emotions) as a function of making the world a better place?

Concerns about myself, others and nature (e.g., Stern \& Dietz, 1994; Stern, Dietz, \& Kalof, 1993; Merchant, 1992), and emotional reactions of hope and fear (e.g., Ojala, 2005; 2007) were included as dependent variables. Two hypotheses were tested, predicting that concerns and feelings will be affected differently by environment-related egoism and altruism.

Hypothesis 1:
1) Participants assessed as "high" on egoism will be more concerned about myself-related issues than issues related to others and nature (a self-benefit goal—Batson, 1995).

2) Participants assessed as "high" on altruism will be more concerned about all types of issue, but mostly about issues related to others and nature (acting more selflessly, according to empathy-altruism hypothesis-Batson, 1991; 1998).

Hypothesis 2:

1) Participants assessed as "high" on egoism will be more afraid for local environment issues than for global issues as the former is closer and a less abstract geographical dimension for the individual (a type of attachment, "kinship"; Neyer \& Lang, 2003; Maner \& Gailliot, 2007). They will strive for local material and social self-benefits (Schroeder et al., 1995). Those with a high level of egoism will also be more hopeful regarding both environments indicating a sense of shared self ("unintended consequences"; Batson et al., 2003), which in the long run will benefit the individual (Cialdini et al., 1997), but mostly the local environment according to the self-benefit goal hypothesis (Batson, 1995).

2) Participants assessed as "high" on altruism will be more afraid and less hopeful for both environments, but more afraid and less hopeful for the whole world (acting more selflessly, according to empathy-altruism hypothesis-Batson, 1991; 1998).

\section{Method}

\section{Sample}

A total of 1000 households (randomly identified from a population register) located within the City of Gothenburg (Göteborg, Sweden, $57^{\circ} 42^{\prime} \mathrm{N}, 11^{\circ} 58^{\prime} \mathrm{E}$-with a population of ca. $500,000)$ and 1000 tourists visiting the town were sent a "climate survey". This comprised a number of sections including questions about demographic variables, climate, climate-changerelated behaviours, attitudes, etc. Data on climate-change- related beliefs, concerns, hope and fear will be reported in the present article.

Procedures and response rates. After two contacts 1257 responses from 681 residents and 576 tourists were received; comprising $50.5 \%$ women and $49.5 \%$ men, distributed similarly across six age groups of $-25(11.8 \%), 26-35(16.9 \%), 36-45$ (20.5\%), 46 - 55 (18.7\%), $55-65(16.7 \%)$ and $66+(15.5 \%)$.

\section{Measures}

Value orientations. Climate-change-related beliefs were used as a measure of environment-related egoism vs. altruism, derived from Hansla et al. (2008; see also Schultz, 2001): Egoism 1) Laws that protect the environment limit my choices and personal freedom and 2) Protecting the environment will threaten jobs for people like me (two items, $\alpha=.64$ ); Altruism: 3 ) Effects of climate change on public health are worse than people realize; 4) Pollution generated in one country harms people all over the world (two items, $\alpha=.56$ ). Participants were asked to respond to these statements on a 7-point Likert scale ranging from 1 (completely disagree) to 7 (completely agree). These scales were first transformed into a general variable of egoism vs. altruism by calculating a mean value for the statements (1) $+(2)$ and $(3)+(4)$ respectively. Then, subjects scoring lower than $4(1-3)$ were considered to be "low" and those higher than $5(5-7)$ were considered to be "high" on the respective independent variable of Egoism (low vs. high) vs. Altruism 
(low vs. high)

Psychological research usually recommends three types of method for splitting a continuously scaled variable: 1) At the midpoint of the scale; 2) At the median; and 3) At the top and bottom third, which is used in the present paper because the aim of this study was to investigate contrasting positions (Knez, 2005) of "low" vs. "high" estimations on egoism and altruism respectively. According to DeCoster, Iselin and Gallucci (2009: p. 364) a dichotomization of a continuous variable/measure is justified when using "extreme group analysis"; that is, including only individuals scoring low and high on a scale.

Concerns. Climate-change-related concerns related to myself, others and nature were used, derived from Hansla et al. (2008): Myself - "I am concerned about climate change because of the consequences for myself, my lifestyle, my health, my future." (four items, $\alpha=.91$ ); Others- “...because of the consequences for all people, people in my country, children, my children." (four items, $\alpha=.87$ ); Nature- “... .because of the consequences for plants, marine life, birds, other animals (four items, $\alpha=.91$ ). This was conducted using a 7-point Likert scale ranging from 1 (completely disagree) to 7 (completely agree).

Climate-change-related fear and hope (Ojala, 2005) were measured with one question (two items) respectively: Fear"How much do you feel afraid for the place where you live (item 1) vs. the whole world (item 2) when you think about climate change risks?" Hope-_How much do you feel hopeful for the place where you live (item 1) vs. the whole world (item 2) when you think about climate change risks?" Participants were asked to respond to these questions on a 7-point Likert scale ranging from 1 (not at all) to 7 (very much).

\section{Design, Independent and Dependent Variables}

A non-equivalent comparison-group quasi-experimental design (McGuigan, 1983) was used. Compared with a "true experiment" (Liebert \& Liebert, 1995), this means that the inferences drawn about the causal relationships between independent and dependent variables are considered to be weaker.

Independent variables. Two independent variables of environment-related Egoism (low vs. high; 890 vs. 79 participants) and Altruism (low vs. high; 91 vs. 806 participants) were used in the study. Due to (1) the cross-sectional data and (2) the aim of this study, i.e. to investigate concerns and affect in "polarized" individuals ("low" vs. "high" on egoism vs. altruism), two one-way analyses of variance were performed involving independent variables of Egoism and Altruism respectively. Accordingly, the aim of this study was to investigate differences related to "low" vs. "high" individuals in respective value orientation of egoism and altruism.

Dependent variables included 12 concern statements $(4 \times 3$ myself/others/nature) and 8 affect questions ( 2 fear +2 hope $\times$ 2 types of environment).

\section{Results}

The aim of this study was to analyse the effects of "polarized" individuals of "low" and "high" environment-related egoism vs. altruism on climate-change-related concerns and affect. Before doing so we have to ensure that the classification procedure used (see Method/Measures/Value orientations) provides a better test of contrasting position than a correlational analysis. This was done by performing: 1) A MANOVA for each dependent variable with egoism and altruism as independent variables, especially testing for the interaction effects of egoism (low vs. high) X altruism (low vs. high); and 2) A regression analysis involving the two general scales of egoism and altruism (see Method/Measures/Value orientations), testing for the degree of relationship between these two scales.

The two-way MANOVAs showed no significant interaction effects of egoism and altruism ( $p>.16$ for concerns; $p>.09$ for fear; $p>.30$ for hope), and the regression analysis showed no significant association between the two scales of egoism and altruism $(p>.61)$. Thus, the value orientations of environment-related egoism and altruism are indicated to be two rather than one egoism-altruism dimension demonstrating an uncorrelated (regression analysis), unrelated (MANOVA) relationship between the two constructs. We can, therefore, proceed safely in analysing the "contrasting positions" of "low" vs. "high" individuals in respective value orientation of environmentrelated egoism and altruism on climate change related concerns and affect.

In addition, the $S D$ differences between the cells (unequal cell sizes of low vs. high egoism/altruism) for the dependent variables of concerns, fear and hope were between .0 and .4 ; thus, indicating no or a very small potential distortion of $\alpha$ levels (Tabachnick \& Fidell, 1989). Also, the statistical software SPSS uses the "Type III model" as default, taking in to account unweighted means.

The Result section comprises two headings, related to Hypotheses 1 and 2 respectively (see Introduction): 1) "Effects of Egoism vs. Altruism on Concerns"; and 2) "Effects of Egoism vs. Altruism on Fear and Hope".

\section{Effects of Egoism vs. Altruism on Concerns}

Two MANOVAs were performed involving 12 concerns as a dependent variable ( 4 myself- +4 others- +4 nature-related); one analysis for each of the two value orientations of egoism and altruism respectively. Thus, two one-way analyses of variance were performed involving "low" vs. "high" individuals in respective analysis and independent variable of Egoism vs. Altruism.

Egoism. A main significant effect of "low" vs. "high" on concerns was obtained, Wilk's Lambda $=.96, F(12,836)=$ $3.09, p<.01, \eta^{2}=.04$. As can be seen in Figure 1 and as predicted (Hypotheses 1a), this effect was associated only with the myself-related concerns for: Myself $\left(p<.01, \eta^{2}=.01\right)$; My lifestyle $\left(p<.01, \eta^{2}=.03\right)$; My health $\left(p<.01, \eta^{2}=.01\right)$; and My future ( $p=.09$, a tendency to a significant result). Thus, participants assessed as "high" compared to those assessed as "low" on egoism were those most concerned for the myselfrelated issues regarding climate change impact; especially for "my lifestyle" (largest difference between "low" and "high").

Altruism. A main significant effect of "low" vs. "high" on concerns was obtained, Wilk's Lambda $=.64, F(12,775)=$ $36.46, p<.01, \eta^{2}=.36$. As predicted (Hypotheses $1 \mathrm{~b}$ ) this effect was associated with all types of concerns: Myself $(p<.01$, $\left.\eta^{2}=.58\right)$; My lifestyle $\left(p<.01, \eta^{2}=.54\right)$; My health $\left(p<.01, \eta^{2}\right.$ $=.59)$; My future $\left(p<.01, \eta^{2}=.61\right)$; All people $\left(p<.01, \eta^{2}\right.$ $=.82)$; People in my country $\left(p<.01, \eta^{2}=.72\right)$; Children $(p$ $\left.<.01, \eta^{2}=.83\right)$; My children $\left(p<.01, \eta^{2}=.78\right)$; Plants $(p<.01$, $\left.\eta^{2}=.81\right)$; Marine life $\left(p<.01, \eta^{2}=.85\right)$; Birds $\left(p<.01, \eta^{2}\right.$ $=.81)$; and Other animals $\left(p<.01, \eta^{2}=.83\right)$. Thus, participants assessed as "high" compared to those assessed as "low" on 


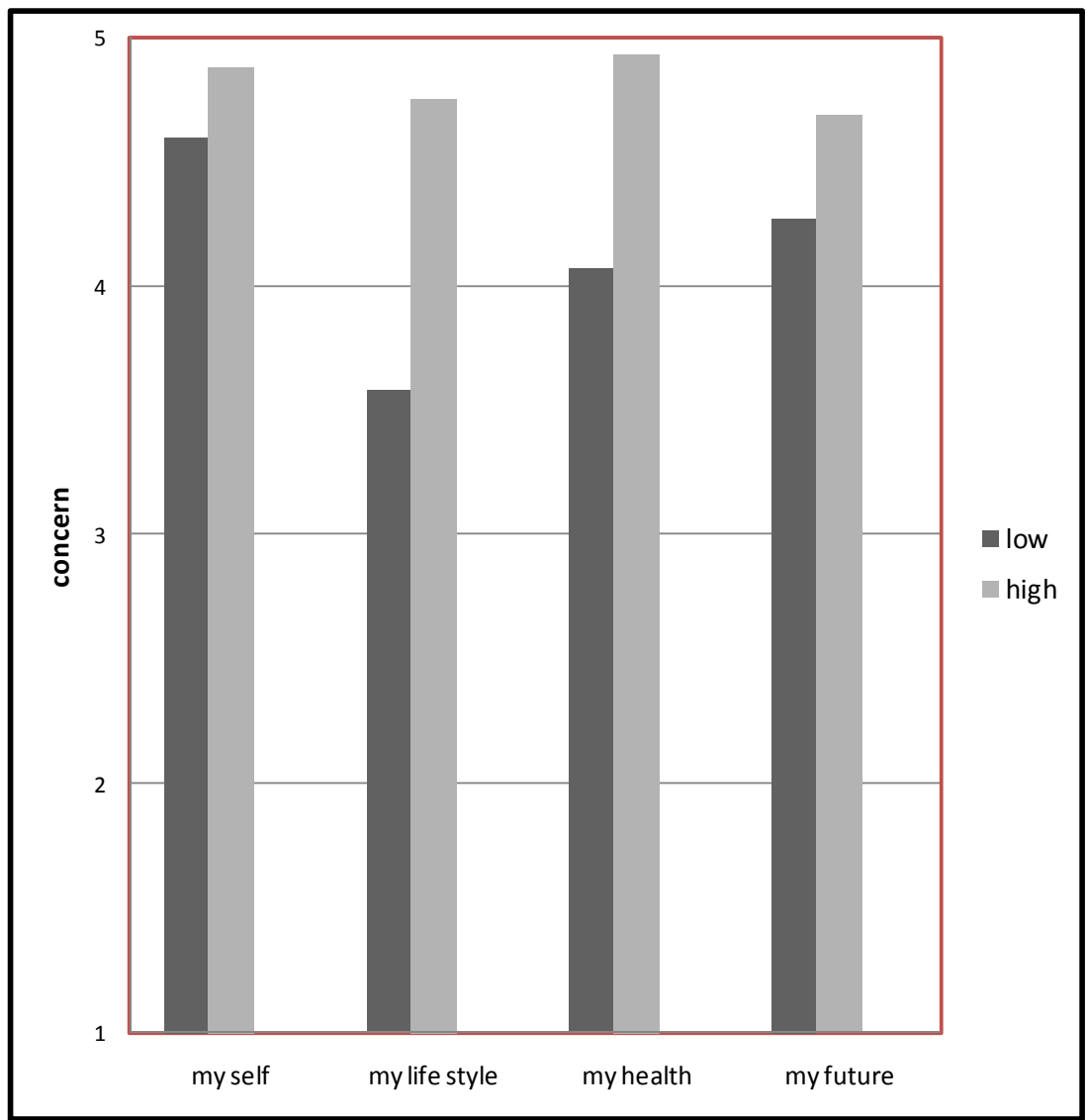

Figure 1.

Mean climate change related concern for myself-related concerns in participants estimated to be "low" vs. "high" on Egoism.

altruism were those most concerned about issues related to myself, others and nature. In addition, they ("high") were shown to be mostly concerned about others- and nature-related issues and least concerned for "my lifestyle" regarding climate change impact (see Figure 2).

\section{Effects of Egoism vs. Altruism on Fear and Hope}

Four MANOVAs were performed (involving 2 dependent variables of fear and hope by 2 types of environments); two analyses for each of the two value orientations of egoism and altruism respectively.

Egoism. A main significant effect of "low" vs. "high" on fear was obtained, Wilk's Lambda $=.98, F(2,966)=8.58, p<.01$, $\eta^{2}=.02$, associated with the place where I live $\left(p<.01, \eta^{2}\right.$ $=.01$ ). As predicted (Hypothesis 2a), participants assessed as "high" on egoism were shown to be more afraid for the climate change impact on their local environment than participants assessed as "low" on egoism $(M=4.0, S D=.19$ vs. $M=3.38$, $S D=.06)$.

A main significant effect of "low" vs. "high" on hope was also obtained, Wilk's Lambda $=.97, F(2,958)=16.18, p<.01$, $\eta^{2}=.03$, associated with place where I live $\left(p<.01, \eta^{2}=.01\right)$ and whole world $\left(p<.01, \eta^{2}=.03\right)$. As can be seen in Figure 3, participants assessed as "high" compared to those assessed as "low" on egoism were shown to be more hopeful for both types of milieu. However and as predicted (Hypothesis 2a), they were more hopeful for the local environment than for the whole world, $t(78)=4.76, p<.01, d=.30$.

Altruism. A main significant effect of "low" vs. "high" on fear was obtained, Wilk's Lambda $=.86, F(2,894)=74.97, p$ $<.01, \eta^{2}=.14$, associated with place where I live $\left(p<.01, \eta^{2}\right.$ $=.11)$ and whole world $\left(p<.01, \eta^{2}=.12\right)$. As predicted (Hypothesis 2b), participants assessed as "high" on altruism were shown to be more afraid for climate change impact related to both types of milieu than participants assessed as "low" on altruism. However, they were more fearful for the whole world than for the local environment, $t(805)=18.56, p<.01, d=1.18$ (see Figure 4).

A main significant effect of "low" vs. "high" on hope was also obtained, Wilk's Lambda $=.98, F(2,886)=9.28, p<.01$, $\eta^{2}=.02$, associated with place where I live $\left(p=.03, \eta^{2}=.01\right)$ and whole world $\left(p<.01, \eta^{2}=.02\right)$. As can be seen in Figure 5 and as predicted (Hypothesis 2b), participants assessed as "high" compared to those assessed as "low" on altruism were shown to be less hopeful for both types of milieu. However, they were less hopeful for the whole world than for the local environment, $t(797)=20.06, p<.01, d=.87$.

\section{Discussion}

The idea that concerns for and emotional reactions to the consequences of climate change may be due to an environment-related type of egoism vs. altruism was tested. It was 


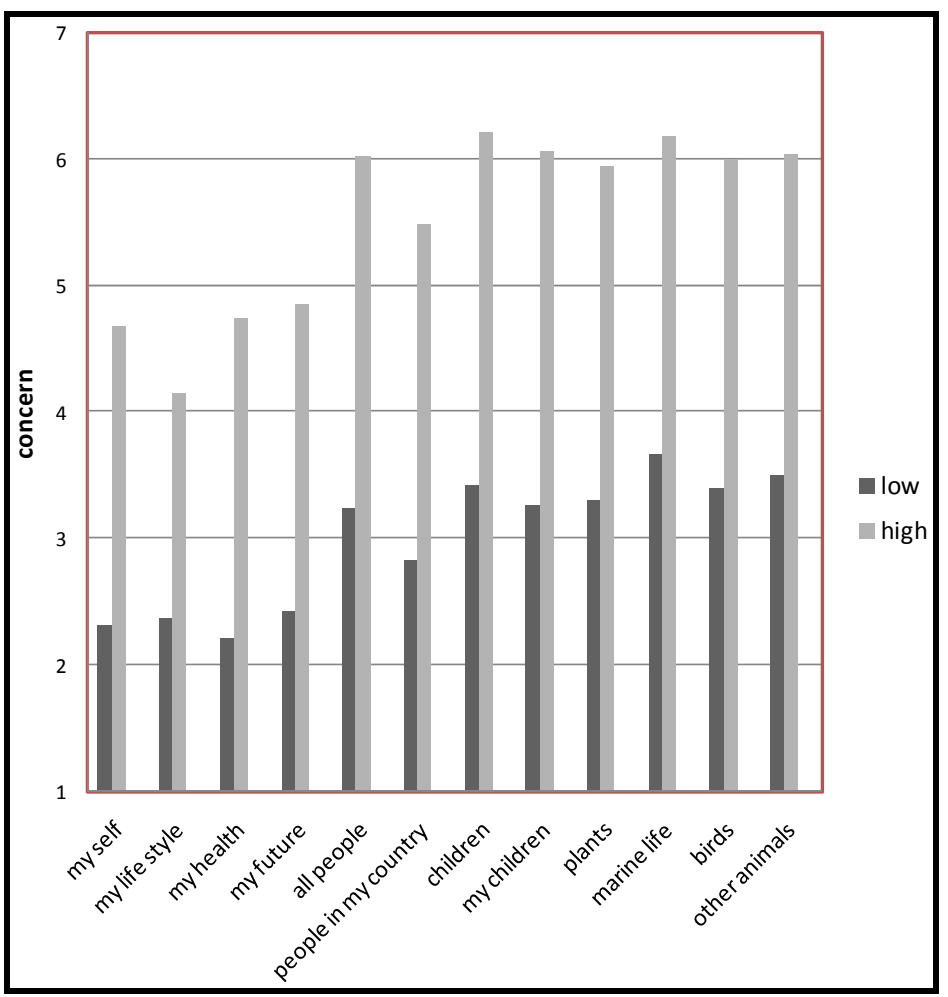

Figure 2.

Mean climate change related concern for myself-, others- and nature-related concerns in participants estimated to be "low" vs. "high" on Altruism.

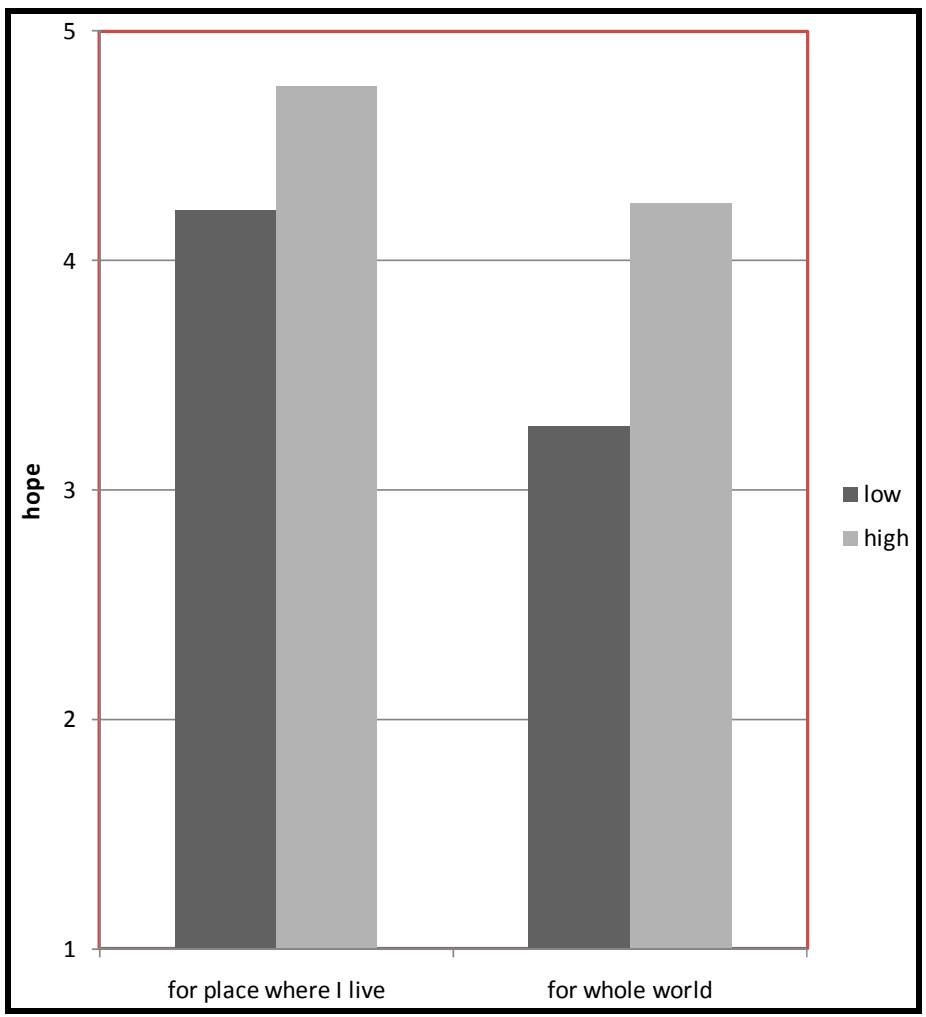

Figure 3.

Mean climate change related hope for neighbouring environment vs. whole world in participants estimated to be "low" vs. "high" on Egoism. 


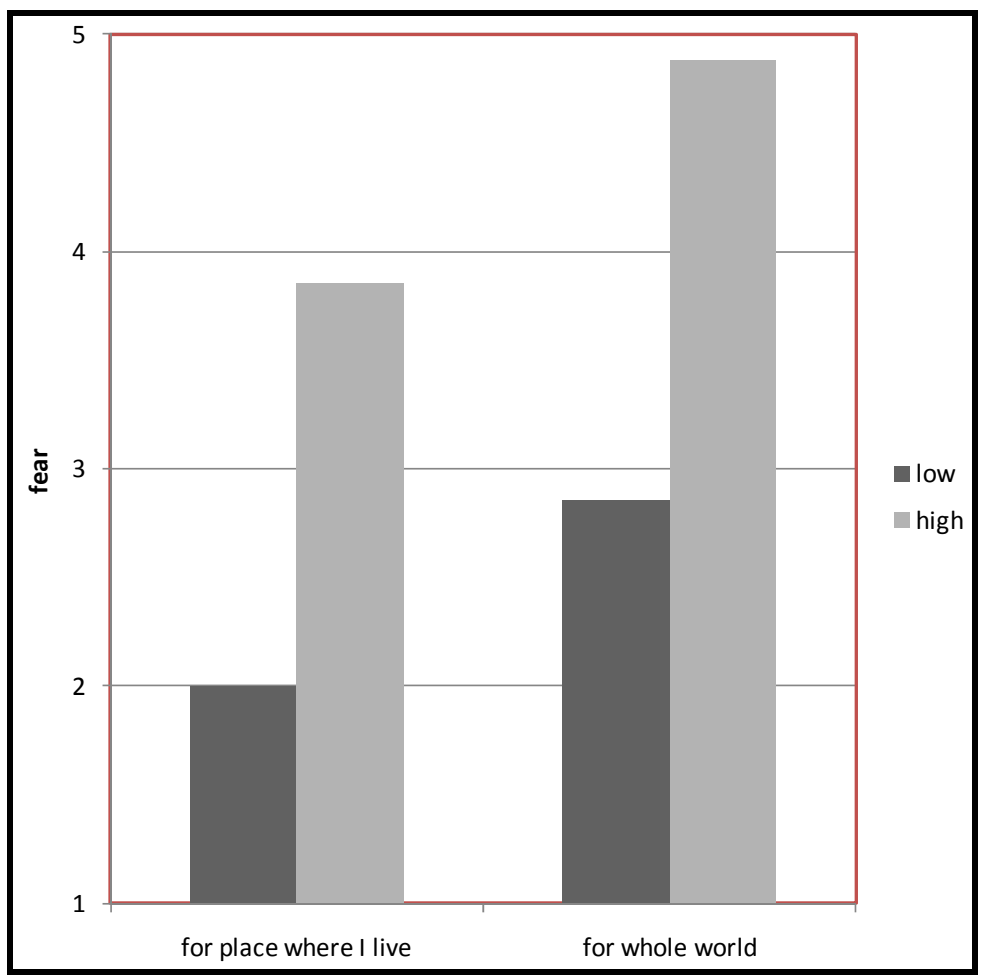

Figure 4.

Mean climate change related fear for neighbouring environment vs. whole world in participants estimated to be "low" vs. "high" on Altruism.

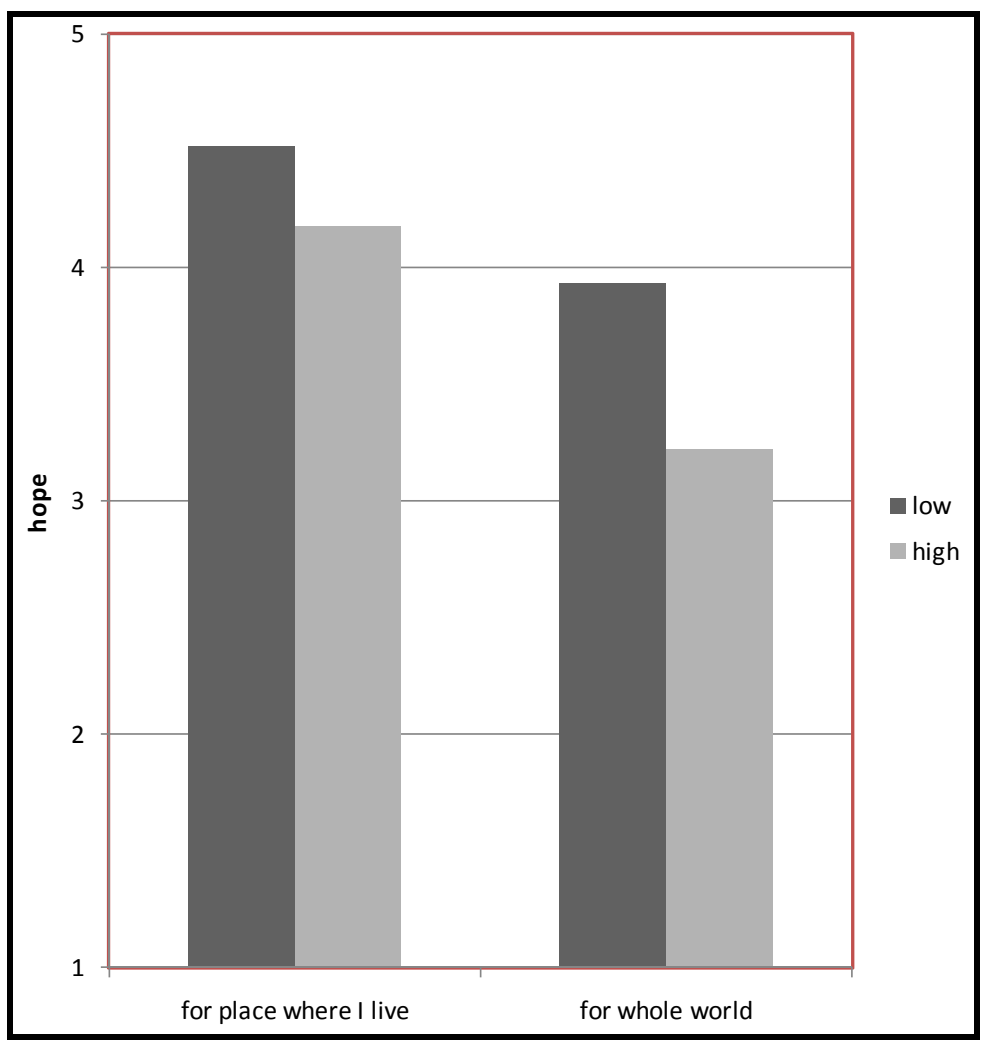

Figure 5.

Mean climate change related hope for neighbouring environment vs. whole world in participants estimated to be "low" vs. "high" on Altruism. 
shown that participants assessed as "high" compared to those assessed as "low" on egoism were those most concerned for myself-related issues regarding climate change impact, indicating a self-benefit goal (Batson, 1995) in the former group of individuals. They ("high") were also shown to be more afraid for their local milieu than the global situation. This suggests a type of attachment ("kinship" Neyer \& Lang, 2003; Maner \& Gaillot, 2007) between me and place where I live and thus a motive for local material and social self-benefits (Schroeder et al., 1995).

Participants assessed as "high" on egoism were shown to be more hopeful for both types of milieu suggesting a sense of shared self, benefiting oneself in the long run (Cialdini et al., 1997). This result implies also a reduction of aversive arousal in the individual related to the suffering of others that might upset oneself. "...The ultimate goal is the self-benefit of having one's own discomfort go away" (Batson et al., 2003: p. 284); hence, a type of "unintended consequence" which is: "...a result of acting to reach a goal but is not itself sought as a goal" (Batson et al., 2003: p. 281). However, and as predicted, participants assessed as "high" on egoism were shown to be more hopeful for their local environment than for the whole world, thus indicating a self-benefit goal (Batson, 1995) in this group of individuals.

On the other hand, participants assessed as "high" on altruism were shown to be more concerned for issues relating to others and nature than participants with a "low" altruism score; thus, acting more selflessly according to the empathy-altruism hypothesis (Batson, 1991; 1998). They were also shown to be more afraid and less hopeful for both types of milieu than participants assessed as "low" on altruism. However, and as predicted, they were most fearful and less hopeful for the whole world with regard to climate change impact; thus, acting more selflessly according to the empathy-altruism hypothesis (Batson, 1991; 1998).

In sum, the environment-related value orientations of egoism and altruism were shown to significantly affect persons' concerns and emotions, meaning that egoism and altruism may prompt concerns and convey feelings differently about the climate change issue. This indicates that people undertake prosocial actions differently "in an attempt to increase the welfare of the world."(Oceja \& Saldago, 2012), and suggests that the ethical dimensions of climate change may be part of the judgment analyses involved in the global climate change issue (Gardiner, 2006; Posas, 2007). In other words, a self-benefit-goal-motive (a type of an instrumental value about the worth of milieu-e.g. Light \& Katz, 1996) was indicated in individuals assessed as "high" on egoism, whereas a pro-social-goal-motive (a type of an intrinsic value about the worth of milieu-e.g. Leopold, 1949/1987) was indicated in individuals assessed as "high" on altruism - alluding to the words of Proverbs 11:25: “...a generous man will prosper, he who refreshes others will himself be refreshed" (cited in Post, 2005).

Correspondingly, when encouraging sustainable development, policy and pro-environmental actions (UNCED, 1992; UNWTO, 2008; Menzel \& Bögeholz, 2010), we have to bear in mind people's world views grounded in environment-related selfishness vs. unselfishness, indicating different goal-directed motives as means to benefit oneself vs. others; and that evaluations of, and decision making about, environment-related issues are not only cognitive, intellectual, activities but emotional ones as well (Slovic et al., 2002; Leiserowitz, 2006).

\section{REFERENCES}

Batson, C. D. (1991). The altruism question: Toward a social psychological answer. Hillsdale, NJ: Erlbaum.

Batson, C. D. (1995). Prosocial motivation: Why do we help others? In A. Tesser (Ed.), Advanced social psychology (pp. 333-381). New York: McGraw-Hill.

Batson, C. D. (1998). Altruism and prosocialbehavior. In D. T. Gilbert, S. T. Fiske, \& G. Lindzey (Eds.), The handbook of social psychology (4th Edition, pp. 282-316). Boston, MA: McGraw-Hill.

Batson, C. D., Van Lange, P. A. M., Ahmad, N., \& Lishner, D. A. (2003). Altruism and helping behavior. In M. A. Hogg, \& J. Cooper (Eds.), The SAGE handbook of social psychology (pp. 279-295). London: SAGE Publications.

Biel, A., \& Thögerson, J. (2007). Activation of social norms in social dilemmas: A review of the evidence and reflections on the implications for environmental behavior. Journal of Economic Psychology, 28, 93-112. http://dx.doi.org/10.1016/j.joep.2006.03.003

Boehnke, K., Fuss, D., \& Rupf, M. (2001). Values and well-being: The mediating roles of worries. In P. Schmuck, \& K. M. Sheldon (Eds.), Life-goals and wellbeing: Towards a positive psychology of human striving (pp. 85-101). Seattle: Hogrefe \& Huber Publishers.

Bonnes, M., \& Bonaiuto, M. (2002). Environmental psychology: From spatial-physical Environment to sustainable development. In R. B. Bechtel, \& A. Churchman (Eds.), Handbook of environmental psychology (pp. 28-54). New York: John Wiley \& Sons.

Böhm, G., \& Pfister, H.-R. (2001). Mental representations of global environmental risks. Research in Social Problems and Public Policy, 9, 1-30. http://dx.doi.org/10.1016/S0196-1152(01)80022-3

Cook, D. M., Boyd, E. A., Grossmann, C., \& Bero, L. A. (2009). Journalists and conflicts of interest in science: Beliefs and practices. Ethics in science and environmental politics, 9, 33-40. http://dx.doi.org/10.3354/esep00100

Cialdini, R. B., Brown, S. L., Lewis, B. P., Luce, C., \& Neuberg, S. L. (1997). Reinterpreting the empathy-altruism relationship: When one into one equals oneness. Journal of Personality and Social Psychology, 73, 481-494. http://dx.doi.org/10.1037/0022-3514.73.3.481

DeCoster, J., Iselin, A.-M. R., \& Galluci, M. (2009). A conceptual and empirical examination of justifications for dichotomization. Psychological Methods, 4, 349-366. http://dx.doi.org/10.1037/a0016956

Dietz, T., Fitzgerald, A., \& Shwom, R. (2005). Environmental values. Annual Review of Environmental Resources, 30, 335-372. http://dx.doi.org/10.1146/annurev.energy.30.050504.144444

Ehrich, P. R. (2002). Human nature, nature conservation and environmental ethics. BioScience, 52, 31-43. http://dx.doi.org/10.1641/0006-3568(2002)052[0031:HNNCAE]2.0. $\mathrm{CO} ; 2$

Garcia-Mira, R., Real, J. E., \& Romay, J. (2005). Temporal and spatial dimensions in the perception of environmental problems: An investigation of the concept of environmental hyperopia. International Journal of Psychology, 1, 5-10. http://dx.doi.org/10.1080/00207590444000078

Gardiner, S. M. (2006). A perfect moral storm: Climate change intergenerational ethics and the problem of moral corruption. Environmental Values, 15, 397-413. http://dx.doi.org/10.3197/096327106778226293

Hansla, A., Gamble, A., Juliusson, A., \& Gärling, T. (2008). The relationships between awareness of consequences, environmental concern, and value orientations. Journal of Environmental Psychology, 28, 1-9. http://dx.doi.org/10.1016/i.jenvp.2007.08.004

Hanson, K. C., \& Ostrand, K. G. (2011). Potential effects of global climate change on National Fish Hatchery operations in the Pacific Northwest, USA. Aquaculture Environment Interactions, 1, 175-186. http://dx.doi.org/10.3354/aei00018

Hardin, G. (1968). The tragedy of the common. Science, 162, 12431248. http://dx.doi.org/10.1126/science.162.3859.1243

Henry, A. D., \& Dietz, T. (2012). Understanding environmental cognition. Organization \& Environment, 3, 238-258. http://dx.doi.org/10.1177/1086026612456538

Hoffman, A. J., \& Sandelands, L. E. (2005). Getting right with nature: Anthropocentrism, ecocentrism, and theocentrism. Organization \& 
Environment, 2, 141-162.

http://dx.doi.org/10.1177/1086026605276197

IPCC (2007). Intergovernmental Panel on Climate Change. AR4 Synthesis report, Full Report.

http://www.ipcc.ch/pdf/assessment-report/ar4/syr/ar4_syr.pdf

Jordan, S. M. (2007). Ethical risks of attenuating climate change through new energy systems: The case of a biofuel system. Ethics in Science and Environmental Politics, 9, 23-29.

Karpiak, C., \& Baril, G. L. (2008). Moral reasoning and concern for the environment. Journal of Environmental Psychology, 28, 203-208. http://dx.doi.org/10.1016/j.jenvp.2007.12.001

Koppe, C. G., Jendritzky, R. S., Kovats, \& Menne B. (2004). Heat waves: Risks and responses. Copenhagen: World Health Organization.

Kortenkamp, K.V., \& Moore, C. F. (2006). Time, uncertainty, and individual differences in decisions to cooperate in resource dilemmas. Personality and Social Psychology Bulletin, 5, 603-615.

Knez, I. (2005). Attachment and identity as related to a place and its perceived climate. Journal of Environmental Psychology, 25, 207218. http://dx.doi.org/10.1016/j.jenvp.2005.03.003

Kurz, T., Augoustinos, M., \& Crabb, S. (2010). Contesting the "national interest" and maintaining "our lifestyle": A discursive analysis of political rhetoric around climate change. British Journal of Social Psychology, 49, 601-625. http://dx.doi.org/10.1348/014466609X481173

Light, A., \& Katz, E. (1996). Environmental pragmatism. London: Routledge.

Leiserowitz, A. (2006). Climate change risk perception and policy preferences: The role of affect, imagery, and values. Climate Change, 77, 45-72. http://dx.doi.org/10.1007/s10584-006-9059-9

Leopold, A. (1949/1987). A sand county almanac and sketches here and there. New York: Oxford University Press.

Lewin, K. (1951). Field theory in social science. New York: Harper.

Liebert, R. M., \& Liebert, L. L. (1995).Science and behavior: An introduction to methods of psychological research. New York: Prentice Hall.

Loewenstein, G. F., Weber, E. U., Hsee, C. K., \& Welch, N. (2001). Risk as feelings. Psychological Bulletin, 2, 267-286. http://dx.doi.org/10.1037/0033-2909.127.2.267

Maner, J. K., \& Gailliot, M. T. (2007). Altruism and egoism: Prosocial motivations for helping depend on relationship context. European Journal of Social Psychology, 37, 347-358 http://dx.doi.org/10.1002/ejsp.364

Maner, J. K., Luce, C. L., Neuberg, S. L., Cialdini, R. B., Brown, S., \& Sagarin, B. J. (2002). The effects of perspective taking on helping: Still no evidence for altruism. Personality and Social Psychology Bulletin, 28, 1601-1610. http://dx.doi.org/10.1177/014616702237586

Markham, A. (1996). Potential impacts of climate change on ecosystems: A review of implications for policymakers and conservation biologists. Climate Research, 6, 179-191. http://dx.doi.org/10.3354/cr006179

Marx, S. M., Weber, E. U., Orlove, B. S., Leiserowitz, A., Krantz, D. H., Roncoli, C., \& Phillips, J. (2007). Communication and mental processes: Experiential and analytic processing of uncertain climate information. Global Environmental Change, 17, 47-58. http://dx.doi.org/10.1016/j.gloenvcha.2006.10.004

Menzel, S., \& Bögeholz, S. (2010). Values, beliefs and norms that foster Chilean and German pupils' commitment to protect biodiversity. International Journal of Environmental \& Science Education, 1, 31-49.

Merchant, C. (1992). Radical ecology: The search for a liveable world. New York: Routledge.

McGuigan, F. J. (1983). Experimental psychology: Methods of research. Upper Saddle River, New Jersey: Prentice Hall, Inc.

Milfont, T. L., Abrahamse, W., \& McCarthy, N. (2011). Spatial and temporal biases in assessments of environmental conditions in New Zealand. New Zealand Journal of Psychology, 40, 56-67.

Neyer, F. J., \& Lang, F. R. (2003). Blood is thicker than water: Kinship orientation across adulthood. Journal of Personality and Social Psychology, 84, 310-321. http://dx.doi.org/10.1037/0022-3514.84.2.310
Oceja, L., \& Salgado, S. (2012). Why do we help? World change orientation as an antecedent of prosocial action. European Journal of Social Psychology, 43, 127-136. http://dx.doi.org/10.1002/ejsp.1925

Ojala, M. (2005). Adolescents' worries about environmental risks: Subjective well-being, values, and existential dimensions. Journal of Youth Studies, 3, 331-347. http://dx.doi.org/10.1080/13676260500261934

Ojala, M. (2007). Hope and worry: Exploring young people's values, emotions, and behaviour regarding global environmental problems. Doctoral Dissertation, Örebro: Örebro University.

Olofsson, A., \& Öhman, S. (2006). General beliefs and environmental concern: Transatlantic comparison. Environment and Behavior, 6, 768-790. http://dx.doi.org/10.1177/0013916506287388

Oreg, S., \& Gerro, T. K. (2006). Predicting proenvironmental behavior cross-nationally: Values, the theory of planned behavior, and valuebelief-norm theory. Environment and Behavior, 38, 462-483. http://dx.doi.org/10.1177/0013916505286012

Peters, E., \& Slovic, P. (2000). The springs of action: Affective and analytical information processing in choice. Personality and Social Psychology Bulletin, 26, 1465-1475. http://dx.doi.org/10.1177/01461672002612002

Posas, P. (2007). Roles of religion and ethics in addressing climate change. Ethics in Science and Environmental Politics, 2007, 31-49.

Post, S. G. (2005). Altruism, happiness, and health: It's good to be good. International Journal of Behavioral Medicine, 2, 66-77. http://dx.doi.org/10.1207/s15327558ijbm1202 4

Rabinovich, A., Morton, T. A., Postmes, T., \& Verplanken, B. (2011). Collective self and individual choice: The effects of inter-group comparative context on environmental values and behaviour. British Journal of Social Psychology, 51, 551-569. http://dx.doi.org/10.1111/j.2044-8309.2011.02022.x

Saad, L. (2002). American sharply divided on seriousness of global warming. Gallup Poll Monthly (Report No. 438, pp. 43-48). Princeton, NJ: Gallup.

Schmuck, P., \& Vlek, C. (2003). Psychologists can do much to support sustainable development. European Psychologist, 2, 66-76.

Schroeder, D. A., Penner, L. A., Dovidio, J. F., \& Piliavin, J. A. (1995). The psychology of helping and altruism: Problems and puzzles. New York: McGraw-Hill.

Schultz, P. W. (2001). The structure of environmental concern: Concern for self, other people, and the biosphere. Journal of Environmental Psychology, 21, 1-13.

Schultz, P. W., Gouveia, V. V., Cameron, L. D., Tankha, G., Schmuck, P., \& Franek, M. (2005). Values and their relationship to environmental concern and conservation behavior. Journal of Cross-Cultural Psychology, 36, 457-475.

http://dx.doi.org/10.1177/0022022105275962

Schwartz, S. H. (1992). Universals in the content and structure of values: Theoretical advances and empirical tests in 20 countries. In M. Zanna (Ed.), Advances in experimental psychology (pp. 1-65). Orlando, FL: Academic Press.

Schwartz, S. H. (1994). Are there universal aspects in the structure and contents of human values? Journal of Social Issues, 50, 19-45. http://dx.doi.org/10.1111/j.1540-4560.1994.tb01196.x

Slovic, P., Finucane, M. L., Peters, E., \& MacGregor, D. G. (2002). The affect heuristic. In T. Gilovich, D. Griffin, \& D. Kahneman (Eds.), Heuristics and biases: The psychology of intuitive judgment (pp. 397-420). New York: Cambridge University Press.

Sparks, P., Jessop, D. C., Chapman, J., \& Holmes, K. (2010). Proenvironmental actions, climate change, and defensiveness: Do selfaffirmations make a difference to people's motives and beliefs about making a difference? British Journal of Social Psychology, 49, $553-$ 568. http://dx.doi.org/10.1348/014466609X471976

Smith, J. B., \& Lenhart, S. S. (1996). Climate change adaptation policy options. Climate Research, 6, 193-201. http://dx.doi.org/10.3354/cr006193

Stehr, N., \& Von Storch, H. (1995). The social construct of climate and climate change. Climate Research, 5, 99-105.

http://dx.doi.org/10.3354/cr005099 
Stern, N. (2006). The economics of climate change: The stern review. Cambridge: Cambridge University Press.

Stern, P. C. (2000). Toward a coherent theory of environmentally significant behavior. Journal of Social Issues, 56, 407-424. http://dx.doi.org/10.1111/0022-4537.00175

Stern, P. C., \& Dietz, T. (1994). The value basis of environmental concern. Journal of Social Issues, 50, 65-84. http://dx.doi.org/10.1111/j.1540-4560.1994.tb02420.x

Stern, P., Dietz, T., \& Kalof, L. (1993). Value orientations, gender, and environmental concern. Environment and Behavior, 25, 322-348. http://dx.doi.org/10.1177/0013916593255002

Stocks, E. L., Lishner, D. A., \& Decker, S. K. (2008). European Journal of Social Psychology, 39, 649-665.

http://dx.doi.org/10.1002/ejsp.561

Sundblad, E.-L., Biel, A., \& Gärling, T. (2007). Cognitive and affective risk judgements related to climate change. Journal of Environmental Psychology, 27, 97-106.

http://dx.doi.org/10.1016/j.jenvp.2007.01.003

Sundblad, E.-L., Biel, A., \& Gärling, T. (2009). Knowledge and confidence in knowledge about climate change among experts, journalists, politicians, and laypersons. Environment and Behavior, 2, 281-302.

Tabachnick, B. G., \& Fidell, L. S. (1989). Using multivariate statistics.
New York: Harper \& Row, Publishers, Inc.

UNCED (United Nations Conference on Environment and Development) (1992). Convention on Biological Diversity. Rio de Janeiro: UNCED.

UNWTO (2008). Climate change and tourism: Responding to global challenges. World Tourism Organization and United Nations Environment. Madrid: World Tourism Organization.

Van Vugt, M. (2002). Central, individual, or collective control? American Behavioral Scientist, 5, 783-800. http://dx.doi.org/10.1177/0002764202045005004

Weber, E. U. (2006). Experience-based and description-based perceptions of long-term risk: Why global warming does not scare us. Climatic Change, 77, 103-120.

http://dx.doi.org/10.1007/s10584-006-9060-3

Wilson, K. M. (2000). Drought, debate, and uncertainty: Measuring reports knowledge and ignorance about climate change. Public Understanding of Science, 9, 1-13. http://dx.doi.org/10.1088/0963-6625/9/1/301

World Resource Institute (2000). World resources 2000-2001-People and ecosystems: The fraying web of life. www.wri.org/wr2000/ 